山्山FFRANÇAISE

$>\mathrm{DE}$

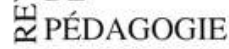

\section{Revue française de pédagogie}

Recherches en éducation

$186 \mid 2014$

Les trajectoires des inspections scolaires en Europe : analyses comparatives

\title{
School inspection in Sweden: historical evolution, resurrection and gradual change
}

L'inspection scolaire en Suède : évolution historique, résurrection et changement graduel

\section{Linda Rönnberg}

\section{(2)enEdition}

Journals

Electronic version

URL: http://journals.openedition.org/rfp/4400

DOI: $10.4000 /$ rfp.4400

ISSN: 2105-2913

Publisher

ENS Éditions

\section{Printed version}

Date of publication: 1 January 2014

Number of pages: $35-45$

ISBN: 978-2-84788-639-9

ISSN: 0556-7807

\section{Electronic reference}

Linda Rönnberg, « School inspection in Sweden: historical evolution, resurrection and gradual change », Revue française de pédagogie [Online], 186 | 2014, Online since 01 January 2017, connection on 01 May 2019. URL : http://journals.openedition.org/rfp/4400; DOI : 10.4000/rfp.4400 


\section{School inspection in Sweden: historical evolution, resurrection and gradual change Linda Rönnberg}

Cet article entend décrire et mettre en évidence à la fois les continuités et les changements dans le cas de l'inspection scolaire suédoise, avec une attention particulière aux justifications et aux usages de l'inspection comprise comme un instrument politique durable et récurrent de gouvernement de l'éducation. Quels rôles et fonctions ont été attribués à l'inspection sous toutes ses formes historiques? À quels moyens et modes de fonctionnement a-t-on eu recours? Comment comprendre à la fois les continuités et les changements qu'ont connus les inspections? L'analyse se fonde sur de la documentation institutionnelle (rapports de commissions, projets de loi) ainsi que sur des recherches et des études antérieures. L'approche théorique retenue entend rendre compte des dynamiques institutionnelles de changement (ou de reproduction) que connaissent les inspections, que ces dynamiques soient drastiques ou incrémentales. Les premières inspections scolaires furent effectuées dès les années 1860. Depuis cette date, les inspections ont été assurées par différentes agences régionales et nationales et leur objet, leur champ d'application et leur intensité ont différé. L'inspection scolaire fut supprimée lors de la mise en œuvre des importantes réformes de décentralisation des années 1990. Mais après un enterrement politique d'une dizaine d'années, elle fut réintroduite en 2003. En 2008, une agence à part entière, l'«Inspection des écoles» (SI, pour "Schools Inspectorate»), fut même constituée pour pousser plus loin l'effort d'inspection. En permettant des changements aussi bien graduels que plus fondamentaux, les inspections apparaissent finalement comme des institutions qui s'adaptent rapidement aux différentes attentes et solutions mises en avant selon les contextes politiques. Comme l'illustre amplement le cas suédois, l'inspection reste, dans son fondement même, une institution qui dure, qui gagne et regagne sans cesse de la légitimité.

Mots-clés (TESE) : inspection, gouvernance, évaluation, politique en matière d'éducation, Suède.

\section{INTRODUCTION}

In general, there is an intense political interest in national school inspection, and national inspectorates are undergoing rapid change and reform in Europe and beyond. The political popularity of the institution is evident, as inspectorates are restructured, reformed, and assigned different, new, or additional missions and aims. Despite changes in the international and national policy environment towards decreasing the importance of 
hierarchical or regulatory instruments of governing -in an era when "governance" replaces vertical "government" and traditional government is being "reinvented" (Pierre \& Peters 2000; Rhodes 2007; Osborne \& Gaebler 1992) - , inspectorates seem to have persisted and successfully stood the test of time. An often cited expression is that one never steps in the same river twice (cf. Peters \& Pierre 2001), but somehow inspection is presumed to do just that: school inspection is a favoured political option deemed efficient and necessary by policy makers, irrespective of the "water" flowing in the education system and even in society as a whole.

School inspection has been a long-standing feature in governing Swedish education. After the first compulsory elementary school system was introduced in 1842, only two decades passed before national school inspectors were appointed in 1861 to help implement the intentions of the reform. For the next 130 years, school inspections remained central tools in the political governing of education, although the intensity, scope, and institutional and organisational forms have varied. In 1991 as a part of a significant restructuring including far-reaching decentralisation of Swedish education, a dramatic decision to close the national agency Skolöverstyrelsen (SÖ) was taken, and school inspection was abolished once the new National Agency for Education (NAE) was formed. In the new and decentralised system of governing education, the national administrative level was supposed to keep schools at arm's length, leaving significant room for manoeuvre to the municipalities, now the authorities responsible for compulsory education. Initially, school inspection in the form of external inspectors engaging in scrutiny of individual schools on a regular basis did not exist. But things soon changed; school inspection was re-established in Sweden after a decade; with politicians from both left and right advocating the reintroduction.

On one hand, school inspection has been a permanent presence in the Swedish education system for more than a century. On the other, the history of Swedish school inspection attests both the drastic dismantling of an inspection agency and the reintroduction of inspection to the system. How can one understand the apparently counterintuitive return to a governing tool associated with hierarchical and bureaucratic ways of governing in an era emphasising, for instance, teacher professionalism, local discretion, and autonomy? This national case provides interesting possibilities for exploring issues of both continuity and incremental as well as more rapid change, and for illuminating the trajectories of school inspection as embedded in national education systems and set- tings. In this context, needless to say, it is important to acknowledge that Swedish education policy developments are not taking place in isolation. On the contrary, the nation-state engages in negotiations and international work, and even if this has not necessarily diminished national central state power (cf. Goodwin \& Grix 2011), the national-international interface is central to an understanding of the national (Lawn \& Grek 2012).

The aim of this paper is to describe and highlight some important continuities and changes in the Swedish school inspection case, with particular emphasis on the justification and use of inspection as an enduring and recurring political instrument to govern education: what roles and functions have been assigned to the inspectorate, what means of operations have been employed, and how can the continuities and changes be understood? The primary focus of the paper is recent decades, but a longer historical backdrop is also provided as it is necessary for understanding later developments.

\section{UNDERSTANDING INSTITUTIONAL CONTINUITY AND CHANGE}

Institutions play an important role in political and societal life but are notoriously difficult to define and conceptualisations range from narrow definitions to all-encompassing ones, including not only formal rules and organisations but also informal norms and conventions for social interaction (cf. North 1993). In a basic sense, however, many definitions agree that institutions are more or less enduring entities that do not change instantly or very easily (Mahoney 2000). Within the analytical tradition of historical institutionalism, institutions are seen as political legacies from historical struggles (Mahoney \& Thelen 2010). Here, the concept of path dependency roughly denotes that once institutions-such as programmes, policies, organisations, and agencies-have been formed, it is very difficult to alter them, and they tend not to deviate from the outlined path. Policy choices made earlier influence subsequent ones.

Path dependency can be seen as "a relatively entrenched way of unifying, organising, and regulating a certain policy field" (Torfing 2001, 286), implying that in education, for instance, certain patterns for steering policy are developed which will influence the shape and contents of coming policies. This, in turn, denotes that during periods of institutional stability, previous policy decisions can serve as good predictors of future ones 
(Thelen \& Steinmo 1992; Peters 1996; Hall \& Taylor 1996; Pierson 2000; cf. Simola et al. 2013; Helgøy \& Homme 2006). Following this logic, it has been said that the historical-institutional approach is better suited to explaining persistence and continuity than it is to explaining change (Peters 1999). However, concepts such as punctuated equilibrium acknowledge that institutions can indeed change, often very dramatically-even though stability is the prevailing state (Pierson 2000). In this paper, I argue that there are reasons to see institutional continuity and change as both blurred and intertwined and want to highlight both processes of more incremental as well as more fundamental change.

Some theoretical developments have aimed to account for the dynamic relationship that underlies both institutional reproduction and change, also encouraging further analysis through concrete cases of different versions of such change (Mahoney \& Thelen 2010). Thelen (2003, 213) argues that models of path dependency need to be complemented by other tools that enable us to account for this relationship, as these processes may be more incremental than usually proposed. Change does not necessarily need to encompass the whole institution but can target and influence parts of it; further, change can be the result of exogenous forces as well as of endogenous institutional circumstances. Departing from this terminology, institutional conversion refers to what happens when existing frameworks come to be enacted in a different way, resulting in institutions' reorientation towards new goals or missions. These shifts can be orchestrated from within the institution, and critics can use conversion strategies to bring about change. Institutional layering involves revisions, additions, and modifications when new elements are added to-but do not replace-old ones: examples are hiring new personnel and implementing new modes or techniques of working. Each revision may be small, but when placed alongside one another, they accumulate and result in a fundamental change. Displacement refers to changes in rules or procedures-for instance, when alternative arrangements are rediscovered and put back into use or recycled. Such changes can be rapid, similar to the notion of punctuated equilibrium, or slow. Institutions also face the risk of drift-erosion stemming from an incapacity to respond to the external context, as when the institution does not respond to environmental changes. Another such risk is exhaustion by slow-moving breakdown, self-destruction from within (Mahoney \& Thelen 2010; Thelen 2000, 2003). These change processes can also be associated with certain characteristics of the change agents, which could described as for instance insurrectionaries, symbionts, subversives or opportunists. These change agents operate in a certain political context which, of course, strongly influences their ability and willingness to act (Mahoney \& Thelen 2010).

Our empirical material consists of policy texts, such as official government publications, as well as a range of secondary sources and scholarly literature. The early history of inspection from 1860 onwards is primarily explored through secondary materials and research publications. More recent processes of reintroducing and later reinforcing inspection (2001-2003 and 2006-2008, respectively) have been scrutinised by collecting all the official documents produced in the two formal decisionmaking processes, from government directions to set up a commission to the final debate and decision in parliament. This material comprises a total of 34 government bills, parliamentary minutes and motions, commission reports, and auditory reports. The texts (primary as well as secondary sources) have been read in relation to the aim of the study by performing a qualitative content analysis (Bergström \& Boréus 2005) of several steps. Initially, relevant sections of text were identified by reading the material, and the selected sections were tentatively grouped according to broad themes (e.g. governing context, changes in formal frameworks, reform waves, inspection in action). In the next step, these passages were read in detail with regard to illuminating the ways that the rules, functions, and operations of the inspectorates have been represented over the years in the changing political context of which they are a part.

\section{GOVERNING SWEDEN AND GOVERNING EDUCATION}

The Social Democratic Party holds a prominent position in Swedish political history. This party has dominated the political scene in the past, thus leaving a distinctive mark on national politics and policy. The Social Democrats have rarely been out of office; exceptions are 1976, 1982, 1991, and more recently 2006 and 2010. The Social Democratic Party has, of course, also influenced education policy to a large extent, traditionally focusing on issues such as equivalence, equality and education as a means for social cohesion. But even if the Social Democrats have constituted a "hegemonic force" (Agius 2007, 585), the nonsocialist opposition has been active in educational issues and has also initiated significant reforms when in office. 
In the wake of extensive decentralisation and deregulation, especially during the 1990s (cf. below), the local level (i.e. the 290 municipalities) received and still have far-reaching discretion in determining how education is to be conducted. The size and organisation of municipal administrations vary significantly, not least because the municipalities vary greatly in size. Municipalities can freely allocate resources and organise teaching and learning with the aim of attaining the national goals. Another important development concerns the profound marketisation of the Swedish education system, a phenomenon that, among other things, has resulted in a rise in what are called free schools, i.e. schools that are open for all students and free of charge that are not operated by a municipality but still tax funded. Even from an international perspective, the Swedish education system is viewed as extensively affected by marketisation. For example, it allows school owners, including risk-capital companies, to earn a profit from the still publicly financed free schools (Rönnberg 2011). Parallel with and in connection to these developments, the national level of government has increased and intensified its control and evaluative activities (cf. Segerholm 2009).

Over the years, school inspections have been carried out by different state agencies and from a comparative perspective, it is important to note that Swedish agencies often are portrayed as largely autonomous. Formally, state agencies are governed by written government assignments, but a ministry and its ministers are not allowed to intervene in individual matters handled by the agency. It is also important to note, however, that an agency is subordinate to a ministry and therefore is a government organisation and a part of the state's administrative apparatus (Pierre 2004). All in all, agencies enjoy both discretion and a powerful position in the Swedish setting. Coupled with extensive informal contacts with the ministry, an agency's expertise clearly places the central agencies in an influential position, and their knowledge is important to the government's administrative efforts (cf. Rothstein 2005).

\section{IN BRIEF: 130 YEARS OF SCHOOL INSPECTION}

This section makes no attempt at a full description of school inspection during such a long historical period; however, several traits deserve to be highlighted. After passing the first compulsory elementary schooling act in 1842, members of parliament submitted motions about appointing inspectors. The Elementary School
Inspectorate (Folkskoleinspektionen) was established in 1861. At that time, the church and ultimately the parish priest were in charge of elementary schooling. The national administration wanted to speed the process of implementing the 1842 Act and to make schooling more homogenous across the country-and indeed, to ensure that schooling was even taking place at all in the rural areas, with inspection a vital tool to accomplish that aim. The number of inspectors was however moderate to begin with; they were either priests or elementary school teachers, and were to personally visit all the elementary schools in their districts, to gather information about their conditions and needs, and to report to the church administration and to the Ministry of Education (Karlsson, Westman \& Andersson 2007).

From the start, inspectors were quite closely connected to the ministry, and both inspectors and ministry staff met to discuss urgent affairs. There was also a common written framework from 1861 stating in detail how the school visits were to be conducted and reported in order to ensure that inspectors applied the same standards and took comparable actions. From this point on, the Inspection agency-ministry relationship and the issue of how to conduct and accomplish valid and comparable inspections have continued to be key points and dilemmas for the Inspectorate to handle. Towards the end of the century, the elementary school teachers formed a union, protesting against the inspections and in particular the religious influence via the church and the priests in carrying out the inspections. Another issue was how the inspections were conducted-for instance, teachers objected to the highly standardised, formal, and authoritative approach, as well as to the perceived lack of situational judgements in each local context (Karlsson, Westman \& Andersson 2007) - issues that would be continuously debated over the years. In 1918, the state agency Skolöverstyrelsen (SÖ) was established and performed the school inspections.

The 1946 School Commission made a distinctive mark on Swedish education, and the subsequent 1950 parliamentary decision to allow experiments with a nine-year comprehensive school also bore consequences for inspection, both regarding how inspection was performed, what it looked at and its institutional affiliation. When county school boards (Länsskolnämnder) were introduced in 1958 as sub-divisions in the SÖ, the formal representation of the church in school-governing bodies was finally terminated. Moreover, this meant that inspectional duties fell to these new regional (but still state-led) county school boards within the SÖ. It was considered important that 
the SÖ retained overall responsibility for determining a standard for schooling, and inspection remained a necessary feature of the system. The inspectors were supposed to help and to give advice about developing and improving local schools. Further, inspections and school visits were to be performed by inspectors with backgrounds or training in education (Lundgren 2011). These officials were to spend a great deal of time in schools and classrooms; observing only one lesson per class was not seen as sufficient. Furthermore, written assignments from a full class of pupils were to be examined-not merely a sample. But over time, it became evident that such high ambitions could not be realised (Thelin 1994). The procedure of how to conduct inspections and what counts as "sufficient evidence" are recurring issues also present in the contemporary discussion of and in the Inspectorate. Historical legacies of inspection are thus recycled and mirrored in later times, pointing to important continuities that persist irrespective of the political and institutional contexts and circumstances. But still and at the same time change is certainly also taking place.

The county school boards within the SÖ were reformed and gradually changed during the 30 or so years they were in operation, and the role and function of inspection were adjusted accordingly, emphasising the importance of acknowledging small and gradual institutional change. Once again inspections were relocated institutionally and organisationally, and practices changed and were layered into one another. To begin with, the administrative tasks took precedence for the county school board inspectors. A decade or so later, in the late 1960s and early 1970s, ideas of decentralisation had started to gain political ground, and this would profoundly affect education and inspection. In the 1970s, development and improvement issues were high on the educational policy agenda. Even so and in contrast, the 1989 bill on education governance (Government bill 1989) declared that inspection was not to interpret political decisions, meaning that the developmental functions of inspection were toned down as its more control-oriented, supervisory role was highlighted and compliance with national regulations put forward as a central task for inspection. Still, national uniformity and educational equivalence were seen as core values for inspection to safeguard (Committee report 2007) - as had been the case earlier. The functions and means of inspection had continually changed and new practices were layered into old ones. However, the regional boards hardly had time to adjust to the new, stricter, and intensified inspections (Lander \& Granström 2000) before unfolding events would lead to their dismantling.

\section{DECENTRALISATION: AGENCIES DISMANTLED AND INSPECTION ABOLISHED}

In the late 1980 s and early 1990 s, several education reforms were launched under both Social Democratic and nonsocialist governments. Decentralisation, deregulation, and marketisation were guiding principles. In education, all employer responsibilities were transferred from the state to the municipalities, a new funding system was introduced, a system of free school choice was set up; at the same time, a new curriculum, grading system, and syllabuses were implemented. The reforms were initiated by a Social Democratic minority government and intensified and carried out by a nonsocialist minority coalition from 1991 to 1994. These developments changed the perception about the centre-local relationship in education as decentralisation was a very prominent feature of the reforms. In fact, from being one of the most centralist education systems in the western world, the system was significantly restructured resulting in one of the most decentralised systems (cf. Dobbins 2014). These far-reaching reforms also had profound implications for the role and function of school inspection.

The Social Democratic government via the Ministry of Public Administration had planned to reform the regional administration which involved the county school boards under the SÖ. This proposal would, however, never be implemented, as the minister of education at the time (and later prime minister), Göran Persson, had another agenda. In a speech Persson gave at the Social Democratic Party congress in late 1990, he declared that there would be no county school boards and no SÖ: it would be terminated altogether, and a new National Agency for Education (NAE; in Swedish, Skolverket), was to be established instead. This radical decision took many by surprise, and the event made Swedish administrative history (Hjort 2006). A reform was to be expected, given earlier reforms aiming at decentralisation and thus reducing the influence from the central state and its administration, but even in this context, the repercussions for the state agencies were remarkable. It was a rapid displacement of an agency that had been around since 1918 , constituting a fundamental break from the previous path. It could be described as a critical juncture, occurring in a political period of "contingency during which the usual constraints on action are lifted or eased" (Mahoney \& Thelen 2010, 7), making Persson's radical move against his own party possible in which a radical shift and an abrupt displacement in the form of a sudden breakdown of an institution came to profoundly change the rules of the game (cf. Mahoney \& Thelen 
$2010,16)$. The rapid displacement of inspection - in the form of the individual scrutiny of public schools on a regular basis performed by employed national inspectors-lasted for almost a decade.

In a way, decentralisation accompanied by increased national control via inspection could be viewed as an expected development: Reduced central activity, for instance due to decentralisation of authority and responsibilities, tends to be accompanied by the introduction of processes and mechanisms that increase central control (Lægreid, Roness \& Rubecksen 2008). But initially the Swedish case took quite a different path: In the wake of the extensive decentralisation reforms and the new system of governing education, Swedish policy makers, via Göran Persson, abolished inspection and made dramatic changes in the role and function of national agencies. National arm's-length support and advice and an overall soft approach were preferred. The dramatic closing of the SÖ was an "exogenous shock" that imposed a new interpretive frame from the outside and did not originate within the agency (Mahoney \& Thelen 2010). Looking at the change agent Göran Persson, he can be described as an insurrectionary, an actor that actively tries to eliminate existing institutions by mobilising against them - a behaviour associated with displacement, often in its rapid form of overturn during a critical juncture period (Mahoney \& Thelen 2010, 25). But what institutional arrangements followed from this rapid displacement?

\section{SETTING UP A NEW AGENCY SUITED FOR A DECENTRALISED EDUCATION SYSTEM}

When the SÖ was abolished after more than 70 years in operation, its former staff was not automatically employed by the new National Agency for Education (NAE); new personnel were hired. The drastic decision to dismantle the state agency and its local boards also had a symbolic function: it was important to signal a decisive break from the former SÖ, traditionally regarded as representing the bureaucratic and inefficient state governing that the decentralist and deregulatory reforms of the late 1980 s and early 1990 s had been meant to resolve. After terminating rather than reforming the current state educational administration, the NAE was set up in 1991 as a completely new agency purportedly better suited to the new and decentralised system of steering Swedish education. Detailed state regulation was replaced with a strategy of governing by objectives. The
NAE's role was to support and promote local development from a distance-to act as a partner with expertise supporting municipalities in their own efforts to develop schools and education in their geographical areas. Thus, there were no reasons to supervise compliance with national regulations via school inspections; rather, the professionals in schools and municipalities were supposed to acquire and use the knowledge best suited to improve their schools, adjusting it to fit local needs (cf. Haldén 1997; Jacobsson \& Sahlin-Andersson 1995).

In short, the NAE was to have an arm's-length relationship with schools and to "halt at the municipal border" (Statskontoret 2005). As a result, the NAE did not examine individual schools or conduct any supervision of schools and municipalities in the form of inspections, with one exception: the NAE still scrutinised the newly established (and at that time, very few) independent free schools. The NAE also investigated formal complaints concerning individual schools or municipalities, but such investigations were few and did not take the form of inspections. This meant that overall, the municipalities were trusted to inspect the schools under their authority as they saw fit, and no legislation or ordinances stated how they should perform their inspection duties, along the lines of the decentralist policy rhetoric that dominated the political scene. There is not much research about how the municipalities actually carried out this task (cf. Lander \& Granström 2000), but there are good reasons to believe that methods varied a great deal and that, for instance, small municipalities in rural areas had very limited capacity to perform such tasks. The Social Democrats were defeated in the 1991 elections, but the new nonsocialist coalition broadly continued to reform education along the lines the previous government had followed. There was overall agreement about the decentralist direction, as well as regarding the need for increased parental choice and allowing education professionals more discretion. However, it was not long before political voices from both left and right were raised about the need for stronger national supervision of schools and municipalities via the NAE. In the early 1990s the Christian Democrats, a part of the government coalition in office, and the Social Democrats, now in opposition, both submitted parliamentary motions exhorting the government to ensure a more active role for the NAE in evaluating and supervising the educational system (Parliamentary Standing Committee on Education 1994). 


\section{AND INSPECTION REEMERGES...}

In 1994 the Social Democrats were back in office, and their annual written assignments to the NAE over the next several years repeatedly urged the agency to exercise more active and direct control, including placing a stronger emphasis on inspecting for compliance with national regulations. But this did not really happen: the agency had been founded on other principles, and these requests did not fit well with the advisory and dialogue-oriented path the agency initially had been commissioned to take (National Audit Office 2001). But the political authorities persisted, insisting on greater national control in education, arguing for the use of the national agency to that end. In 1998 systematic quality reviews targeting municipal education authorities were performed by the NAE on a regular cycle. At the same time, the nonsocialists in political opposition brought forward a demand for a new quality-auditing agency to exercise the same type of control. In 2002, the Social Democratic government presented an educational development plan which stated that individual school inspections were to be given precedence by a reformed NAE (Government development plan 2002). In 2003, the inspectorate was rebuilt, the NAE was divided into two agencies, and individual inspections were prioritised tasks in the reformed NAE. The other agency, the National Agency for School Improvement, would focus on development and support, while the NAE would deal with the more control and compliance oriented issues.

After more than 10 years without national inspections, public schools were now individually visited and inspected by the Swedish state via the NAE. Education was examined at both the municipal and the individual school level, focusing on quality and legal issues, following a six-year cycle targeting the whole school system. The problem being targeted by inspection was framed mainly in terms of safeguarding quality and upholding national equivalence, and political unity emerged around this way of framing the problem towards which inspection was directed. The revived inspections had arisen from a perceived political need to reinforce national control, expressed as the need for greater visibility and clarity regarding the role of the state in a system governed by objectives and results. The national policy makers argued that the municipal responsibility for quality improvement and evaluation had not worked out as intended after the extensive decentralisation reforms and that school results were not improving enough. Inspection was supposed to bring about improvement and also become a tool for collecting valid information (Government development plan 2002; Parliamentary Auditors 2001; cf. Rönnberg 2012). Governing by objectives and results, regarding the latter for instance by means of inspection, became the main strategy forward and by including the ex-post oriented element of controlling results, inspection was rhetorically possible to realign and co-exist with a still decentralist overall policy direction-layering it alongside the previous "arms-length" element and management by objectives.

It was clear that the NAE was gradually being redirected to new and reinvented aims, and how such gradual layering eventually, then, coincided with and culminated in a route taken earlier: that of inspection as a means of governing education. The process leading up to abolishing the SÖ in the 1990s was discussed and debated afterwards, and as Mahoney and Thelen note when institutions represent "still contested settlements based on specific coalitional dynamics, they are always vulnerable to shifts" $(2010,8)$. The non-inspection direction turned out to be an unstable one and after abolishing inspection, political forces wanted to turn the new NAE back to a more control-oriented route, but initially such attempts were not compatible with the internal and overall ideology of the new institution. But then gradually and in the end contrary to the original intentions, the reformed NAE arguably started to look more like the terminated SÖ in terms of its number of staff, ways of functioning and organising, and representing the national administration in governing education as a strong and present force (Nytell 2006). This gradual displacement later paved the way for the resurrection of inspections in 2003-by the very same Social Democrats that were responsible for their previous abolishment. By reintroducing inspection, the "non-inspection path" was effectively but gradually punctuated and rather seems to be a historical parenthesis in the long life of national school inspection.

\section{...AND INSPECTION INTENSIFIES}

In 2006, the nonsocialists returned to office; that year the Conservative, Liberal, Centre, and Christian Democratic Parties banded together and won the national elections under the umbrella of the Alliance for Sweden. As part of its far-reaching education-reform agenda, the new government announced that it intended to intensify school-inspection efforts. The inspection cycle was to be shorter, and overall more resources would be devoted (Alliance for Sweden 2006). The 
questions of who should be conducting the reinforced inspections and whether the existing institutional framework was suited to that task were issues the government attended to after about six months in office. By then, the minister of education from the Liberal Party formed two commissions that prepared the next steps and paved the way for a new Inspection agency (Committee report 2007). The Swedish Schools Inspectorate (SI) opened its gates in October 2008.

The new agency had a deliberate aim to hire Inspectors with more diverse professional backgrounds, such as people with legal training or general social science analytical skills. Unlike to the closing of the SÖ, the former NAE Inspectors were not fired when the new agency was formed, they kept their jobs and were transferred to the new SI but their new colleagues came with other than educational backgrounds. Such layering when new elements are combined with old ones is of importance as inspection is inevitably an embodied activity; it is performed by inspectors, and their views and backgrounds influence inspection practices (cf. Lindgren 2013). The history of Swedish school inspection shows that the recruitment of inspectors is an important step when building and changing an institution, whether these officials were priests or teachers or, as today, individuals trained in law, the social sciences, or education.

Under the nonsocialist government post 2006, the core values of educational equivalence and quality were still held high, as they had been in earlier times and in the Social Democratic period. However, another concept was gaining ground in terms of pupils' academic achievements (Government Commission direction 2007; Committee report 2007). Other justifications were also reiterated that were also present in the discussions leading up to the 2003 reintroduction: inspection was needed to boost local evaluation efforts and to control and assess local developmental work, inspection would provide needed data, and the comparability of reports was to be improved (cf. Rönnberg 2012). Going back to the notion of equivalence, it has been a central and an uncontested part of Swedish education. It was brought forward as an essential value that an inspectorate must safeguard already when the first inspectorate was established more than a hundred years earlier, and it continued to hold a prominent position in the more recent developments when inspection was resurrected and intensified. The concept of equivalence is a fundamental one in the Swedish education policy context but it has changed its meanings, especially since the centralising and comprehensive reforms of the 1960s. Today, and after the exten- sive decentralisation and marketisation/privatisation reforms of the 1990s in particular, the concept is increasingly linked to individual rights, outcomes and choice, rather than to the unifying social-justice dimension it once incorporated. Additional connotations and functions are thus being layered on to the concept, and these too have left their marks on the scope and function of inspection, mirrored in the goals and missions assigned to the inspectorate: a core persists while other renegotiated meanings are added to it, a sign of institutional layering and of how new and old elements can exist side by side within an institution, suggesting a gradual but important change.

In the process leading to its reintroduction in 2003, inspection was not discussed with much reference to other nations or systems. In the process resulting in intensified inspection and the establishment of a new agency, however, some external input was explicitly mentioned (Committee report 2007). External input to the Swedish inspection system suggested, for instance, introducing unannounced school visits and proportionate inspection based on previous inspection history-methods which were not used in the original NAE inspections (Segerholm, 2012). After the SI was formed, international influences however became more pronounced, and international collaboration and exchange are targeting or influencing parts of the way inspection is conducted. And also, importantly enough, serve as a way of legitimising a certain modes of operation, etc. (cf. Grek et al. 2013). But overall, the international influences do not come across as particularly strong forces and initiators of change, and national needs and comparisons, for instance, with other domestic policy areas, such as higher education and social welfare, are articulated by policy makers, while international input does not appear to receive the same interest or explicit attention as a motive for reintroducing inspection.

\section{AND ONWARDS: CONTINUING AND GRADUAL CHANGE...}

Since 2008, the inspectorate has been given more tasks, and political belief in inspection does not seem to have lost ground-quite the contrary. The SI appears to be a prominent political problem solver; it is supposed to address diverse urgent problems in education, such as the way national tests are handled: the inspectorate is now responsible for evaluating teachers' assessments of national tests ("assessing the assessment"). Another 
area in which the SI has been assigned a prominent role is with regard to the independent but tax funded free schools. A government commission covering most but not all political parties advocated greater and stricter control in and of the free-school sector by the SI as a way of resolving the problems that profit making and school closure and sales have caused (Committee report 2013). Still another area is individual complaints filed by stakeholders; the number has increased dramatically, and the $\mathrm{SI}$ is responsible for investigating them. These examples all point to a central feature of inspection as a political instrument: it can be used to resolve a wide range of perceived political problems and can perform quite different activities. Through such amendments and revisions, the Inspectorate's original aims are renegotiated and ultimately changed, albeit not in a way that completely alters the function of the institution. Rather, new and additional tasks are being layered into and placed alongside the original mission and rules. All in all, this points to the importance of not only drastic but also incremental institutional change.

Looking back over the years, an important example illustrating these continuous conversions is how to balance control and development efforts: Is the inspectorate ultimately aiming to provide improvement, support, and feedback, or does it represent the more standardised and non-context-sensitive control and supervision of compliance with formal regulations? As previously shown, this dilemma was evident quite early on, when the teachers' union protested that inspection was too standardised, formal, and authoritative; it also arose later, when the SÖ and Länsskolnämnderna were directed to both more improvement and more control-oriented efforts during different time periods. The more recent developments also show signs of institutional conversion. The improvement-oriented approach in the 2003 inspections performed by the NAE was converted in the new SI starting in 2008 to explicitly target formal regulations, to be standardised in a single format for all compulsory schools, and to directly address pupils' educational achievements. By assigning new and more tasks to the SI after 2008, politicians have further redirected the inspectorate to other missions and aims, such as safeguarding an education system that school choice and the explosive increase of free schools have put under political pressure and stress. Through such gradual conversions, the inspectorate becomes an adaptable and useful tool to suit almost any political circumstance.

\section{... RESULTING IN AN ADAPTABLE AND ENDURING POLITICAL TOOL}

The Swedish school inspection case thus illustrates how inspection can be seen as a supple and adaptable tool of government, inevitably political in nature (cf. Lascoumes \& Le Galès 2007). The inspection tool encompasses a range of activities that can take the form of both "carrots, sticks and sermons" (Vedung 1998), and inspection can be simultaneously directed towards, for instance, legal issues or sanctions and towards economic incentives or means of resource distribution. But it can also at the same time contain more subtle means of governing, such as the promotion of self-evaluation, the transfer of knowledge, and the encouragement of coordination. These activities may be direct (e.g. regulatory sanctions, fiscal instruments) or indirect means of steering, the latter implying a less visible-but notably, not less important-role for the state. Through both radical and gradual change processes, the inspection tool is continually moulded and bended to suit changing circumstances, fending off the risks of permanent institutional drift or exhaustion.

Inspectorates provide a sense of reassurance about the system and function as universal education policy problem solvers, connected to issues of legitimation at the political level (cf. Ozga 2013). The historical development of the Swedish Inspectorate thereby illustrates that school-inspection institutions seem to be readily adaptable to fit different expectations and solutions and school inspection has remained, at its core, an institution that manages to gain and regain legitimacy. If governing activities are regulative, inquisitive, and meditative (Jacobsson 2006), school-inspection institutions appear able to manage activities of all these types. But they do it with different stress and emphasis, and the inspectorate's toolboxes in their different incarnations contain interesting mixes of these activities. At certain historical times the regulative aspects are prominent, and at other times they are played down; consider the relation between control and development efforts.

In this paper, this flexibility in setting up the operations of an inspection system is argued to be a key to understanding its endurance: inspection responds readily to changing political demands by adapting and employing different roles at different times, by gradual as well as more drastic processes of change. Owing to their capacity to encompass both more regulative and more supportive and less coercive means of regulation-albeit still 
connected under the inspection umbrella-inspections become adaptable and favoured as politically convenient solutions. Looking further into the gradual, incremental as well as more drastic change processes highlight the ways in which Inspectorates continue to be vital and enduring political tools of educational governing. School- inspection institutions are perhaps so enduring that it seems hard to ever get them to disappear, as the Swedish case of resurrected inspection amply illustrates.

\author{
Linda Rönnberg \\ Linda.Ronnberg@umu.se \\ Umeå University
}

\section{REFERENCES}

AGIUS G. (2007). "Sweden's 2006 Parliamentary Election and After: Contesting or Consolidating the Swedish Model?". Parliamentary Affairs 60, no. 4, 585-600.

ALLIANCE FOR SWEDEN (2006). "Mer kunskap - en modern utbildningspolitik". <http://www.alliansen.se/om-alliansen/ filarkiv/> (consulted February 1, 2014).

BERGSTRÖM G. \& BORÉUS K. (2005). Textens mening och makt. Metodbok i samhällsvetenskaplig text- och diskursanalys. Lund: Studentlitteratur.

COMMITTEE REPORT (2007). Tydlig och öppen. Förslag till en stärkt utbildningsinspektion. SOU 2007:101. Stockholm: Fritzes.

COMMITTEE REPORT (2013). Friskolorna $i$ samhället. SOU 2013:56. Stockholm: Fritzes.

DOBBINS M. (2014). "Explaining change and inertia in Swedish and French education: A tale of two corporatisms?". Policy Studies 35, no. 3: 282-302.

GOODWIN M. \& GRIX J. (2011). "Bringing Structures Back In: The 'Governance Narrative', the 'Decentred Approach' and 'Asymmetrical Governance' in the Education and Sports Communities". Public Administration 89, no. 2: 537-556.

GOVERNMENT BILL (1989). Skolans utveckling och styrning. Proposition 1988/89:84. Stockholm: Utbildningsdepartementet.

GOVERNMENT COMMISSION DIRECTION (2007). Utbildningsinspektionens framtida inriktning och utformning. Direktiv 2007:80. Stockholm: Utbildningsdepartmentet.

GOVERNMENT DEVELOPMENT PLAN (2002). Utbildning för kunskap och jämlikhet - regeringens utvecklingsplan för kvalitetsarbetet i förskola, skola och vuxenutbildning. Skr 2001/02:188. Stockholm: Fritzes.

GREK S, LAWN M., OZGA J. \& SEGERHOLM C. (2013). "Governing by inspection? European inspectorates and the creation of a European education policy space". Comparative Education 49, no. 4: 486-502.

HALDÉN E. (1997). Den föreställda förvaltningen. En institutionell historia om central skolförvaltning. Stockholm: Stockholms universitet.

HALL P. A. \& TAYLOR R. C. R. (1996). "Political Science and the Three New Institutionalisms' ". Political Studies 44, no. 4: 936-957.

HELGØY I. \& HOMME A. (2006). "Policy Tools and Institutional Change. Comparing education policies in Norway, Sweden and England". Journal of Public Policy 26, no. 2: 141-165.
HJORT S. (2006). Statens kaka. Om nedläggningen av Skolöverstyrelsen och Länsskolnämnderna. Årsböcker i svensk undervisningshistoria. Uppsala: Föreningen för svensk undervisningshistoria.

JACOBSSON B. (2006). "Regulated regulators: Global trends of state transformation". In M.-L. Djelic \& K. Sahlin-Andersson, Transnational Governance. Institutional Dynamics of Regulation, 205-224. Cambridge: Cambridge University Press.

JACOBSSON B. \& SAHLIN-ANDERSSON K. (1995). Skolan och det nya verket. Skildringar från utvärderingens och styrningens tidevarv. Stockholm: Nerenius och Santérus Förlag.

KARLSSON WESTMAN O. \& ANDERSSON I. M. (2007). Pedagogisk utvärdering som styrning. En historia från präster till PISA. Myndigheten för skolutveckling. Stockholm: Liber.

LÆEGREID P., RONESS P. G. \& RUBECKSEN K (2008). "Controlling Regulatory Agencies". Scandinavian Political Studies 31, no. 31: 1-26.

LANDER R. \& GRANSTRÖM K. (2000). "Skolinspektion i England och Sverige. Hjälp till självhjälp eller självstyrning med betslet i munnen?”. Pedagogisk forskning i Sverige 5, no. 3: 215-234.

LASCOUMES P. \& LE GALÈS P. (2007). "Introduction: Understanding Public Policy through Its Instruments - from the Nature of Instruments to the Sociology of Public Policy Instrumentation". Governance 20, no. 1: 1-21.

LAWN M. \& GREK S. (2012). Europeanizing Education. Governing a new policy space. Oxford: Symposium books.

LINDGREN J. (2013). "The Front and Back Stages of Swedish School Inspection: Opening the Black Box of Judgment". Scandinavian Journal of Educational Research, iFirst article, DOI: 10.1080/00313831.2013.838803.

LUNDGREN U. P. (2011). "Skolans huvudmannaskap och styrning - ansvarsfördelning mellan stat, kommun och fristående skolor". Vägval i skolans historia. Tidskrift från föreningen för svensk undervisningshistoria 11, no. 3-4: 13-21.

MAHONEY J. (2000). "Path Dependence in Historical Sociology". Theory and Society 29, no. 4: 507-548.

MAHONEY J. \& THELEN K. (2010). "A theory of gradual institutional change". In J. Mahoney \& K. Thelen, Explaining Institutional Change. Ambiguity, Agency and Power, 1-38. Cambridge: Cambridge University Press.

NATIONAL AUDIT OFFICE (2001). Skolverkets tillsyn. RRV Rapport 2001:24. Stockholm: Riksrevisionsverket. 
NORTH D. C. (1993). Institutionerna, tillväxten och välståndet. Stockholm: SNS Förlag.

NYTELL H. (2006). Från kvalitetsidé till kvalitetsregim. Om statlig styrning av skolan. Uppsala: Uppsala Universitet.

OSBORNE D. \& GAEBLER T. (1992). Reinventing Government. Reading: Addison-Wesley.

OZGA J. (2013). "Accountability as a policy technology: accounting for education performance in Europe". International Review of Administrative Sciences 79, no. 2: 292-309.

PARLIAMENTARY AUDITORS (2001). Statens styrning av skolan: Från målstyrning till uppsökande bidragsförmedling. RR 2001/02:13. Stockholm: Riksdagens Revisorer.

PARLIAMENTARY STANDING COMMITTEE ON EDUCATION (1994). Utbildningsutskottets betänkande 1993/94:UBU07. Stockholm: Riksdagen.

PETERS B. G. (1996). "Political Institutions, Old and New". In R. E. Goodin \& H.-D. Klingeman, A New Handbook of Political Science, 205-222. Oxford: Oxford University Press.

PETERS B. G. (1999). Institutional Theory in Political Science. The "New Institutionalism". London: Pinter.

PETERS B. G. \& PIERRE J. (2001). "Development in intergovernmental relations: towards multi-level governance". Policy \& Politics 29, no. 2: 131-135.

PIERRE J. (2004). "Central agencies in Sweden: A report from Utopia”. In C. Pollitt \& C. Talbot, Unbundled Government. A critical analysis of the global trend to agencies, quangos and contractualisation, 203-215. London: Routledge.

PIERRE J. \& PETERS B. G. (2000). Governance, Politics and the State. Basingstoke: Macmillan.

PIERSON P. (2000). "Increasing Returns, Path Dependence and the Study of Politics". American Political Science Review 94, no. 2: 251-267.

RHODES R. A. W. (2007). "Understanding Governance: Ten Years On". Organization Studies 28, no. 8: 1243-1264.

RÖNNBERG L. (2011). "Exploring the Intersection of Marketisation and Central State Control through Swedish National School Inspection". Education Inquiry 2, no. 4: 689-707.

RÖNNBERG L. (2012). "Reinstating Swedish National School Inspections: The Return of the State". Nordic Studies in Education 32, no. 2: 69-83.
ROTHSTEIN B. (2005). "Från ämbetsverk till ideologiska statsapparater". In B. Rothstein \& L. Vahlne Wästerhäll, Bortom den starka statens politik, 186-221. Stockholm: SNS.

SEGERHOLM C. (2009). "'We are doing well on QAE': The case of Sweden". Journal of Education Policy 21, no. 2: 195-209.

SEGERHOLM C. (2012). Inspection and policy brokering. Europe in Sweden? Paper presented at the European Conference on Educational Research, Cádiz, September 18-21, 2012.

SIMOLA H., RISTO R., VARJO J. \& KAUKO J. (2013). "The paradox of the education race: how to win the ranking game by sailing to headwind". Journal of Education Policy 28, no. 5: 612-633.

STATSKONTORET (2005). Statliga myndigheters reglering av kommunal verksamhet. <http://www.statskontoret.se/ upload/Publikationer/2005/200529.pdf> (consulted February 10, 2012).

THELEN K. (2000). "Timing and Temporality in the Analysis of Institutional Evolution and Change". Studies in American Political Development 14: 101-108.

THELEN K. (2003). "How Institutions Evolve: Insights from Comparative Historical Analysis". In J. Mahoney \& D. Rueschemeyer, Comparative Historical Analysis in the Social Sciences, 208-241. Cambridge: Cambridge University Press.

THELEN K. \& STEINMO S. (1992). "Historical institutionalism in comparative politics". In S. Steinmo, K. Thelen \& F. Longstreth, Structuring Politics. Historical Institutionalism in Comparative Analysis, 1-32. Cambridge: Cambridge University Press.

THELIN B. (1994). Skolinspektörer minns - Minnen och dokument III. Föreningen för svensk undervisningshistoria. Uppsala: Föreningen för svensk undervisningshistoria.

TORFING J. (2001). "Path-Dependent Danish Welfare Reforms: The Contribution of the New Institutionalisms to Understanding Evolutionary Change". Scandinavian Political Studies 24, no. 4: 277-309.

VEDUNG E. (1998). "Policy Instruments: Typologies and Theories". In M.-L. Bemelmans-Videc, R. C. Rist \& E. Vedung, Carrots, Sticks and Sermons. Policy Instruments and Their Evaluation, 21-59. London: Transaction Publishers. 